\title{
Early natural killer cell counts in blood predict mortality in severe sepsis
}

\author{
David Andaluz-Ojeda', Verónica Iglesias², Felipe Bobillo', Raquel Almansa², Lucía Rico², Francisco Gandía ', \\ Ana Ma Loma², Concepción Nieto², Rosa Diego ${ }^{2}$, Epifanio Ramos ${ }^{2}$, Mercedes Nocito², Salvador Resino ${ }^{4}$, \\ Jose M Eiros ${ }^{2}$, Eduardo Tamayo ${ }^{3}$, Raul Ortiz de Lejarazu ${ }^{2}$ and Jesús F Bermejo-Martin² ${ }^{2 *}$
}

\begin{abstract}
Introduction: Host immunity should play a principal role in determining both the outcome and recovery of patients with sepsis that originated from a microbial infection. Quantification of the levels of key elements of the immune response could have a prognostic value in this disease.

Methods: In an attempt to evaluate the quantitative changes in the status of immunocompetence in severe sepsis over time and its potential influence on clinical outcome, we monitored the evolution of immunoglobulins (Igs) (lgG, IgA and IgM), complement factors (C3 and C4) and lymphocyte subsets (CD4+ T cells, CD8+ T cells, B cells (CD19+) and natural killer (NK) cells (CD3-CD16+CD56+)) in the blood of 50 patients with severe sepsis or septic shock at day 1 , day 3 and day 10 following admission to the ICU.

Results: Twenty-one patients died, ten of whom died within the 72 hours following admission to the ICU. The most frequent cause of death $(n=12)$ was multiorgan dysfunction syndrome. At day 1 , survivors showed significantly higher levels of $\lg \mathrm{G}$ and C4 than those who ultimately died. On the contrary, NK cell levels were significantly higher in the patients who died. Survivors exhibited a progressive increase from day 1 to day 10 on most of the immunological parameters evaluated (IgG, IgA, IgM, C3, CD4+, CD8+ T cells and NK cells). Multivariate Cox regression analysis, including age, sex, APACHE II score, severe sepsis or septic shock status and each one of the immunological parameters showed that NK cell counts at day 1 were independently associated with increased risk of death at 28 days (hazard ratio $=3.34,95 \% \mathrm{Cl}=1.29$ to $8.64 ; P=0.013$ ). Analysis of survival curves provided evidence that levels of NK cells at day $1\left(>83 \mathrm{cell} / \mathrm{s} / \mathrm{mm}^{3}\right)$ were associated with early mortality.

Conclusions: Our results demonstrate the prognostic role of NK cells in severe sepsis and provide evidence for a direct association of early counts of these cells in blood with mortality.
\end{abstract}

\section{Introduction}

Severe sepsis (acute organ dysfunction secondary to infection) and septic shock (severe sepsis plus hypotension not reversed by fluid resuscitation) are major healthcare problems that affect millions of individuals around the world each year, killing one in four (and often more) and increasing in incidence [1-3]. Similarly to polytrauma, acute myocardial infarction and stroke, the early initiation of therapy once severe sepsis is established is likely to influence the patient's prognosis. In

\footnotetext{
* Correspondence: jfbermejo@saludcastillayleon.es

${ }^{2}$ Immunology Section and Infection \& Immunity Medical Investigation Unit (IMI), Microbiology and Immunology Service, Hospital Clínico UniversitarioIECSCYL, Avda Ramón y Cajal 3, E-47005 Valladolid, Spain Full list of author information is available at the end of the article
}

consequence, early identification of individuals at risk for bad outcomes is dramatically important in this condition [4].

Because sepsis originates from a microbial infection, host immunity should play a principal role in determining both outcome and recovery. A protective role of naturally produced immunoglobulin G (IgG) in sepsis was described previously [5]. The participation of cellular immunity in this disease is poorly understood, and the available data are controversial [6-8].

Identifying quantitative alterations in key humoral and cellular parameters could have a prognostic value in this condition. In an attempt to evaluate the quantitative changes in the status of immunocompetence in severe
C Biomed Central 
sepsis over time and its potential influence on clinical outcome, we monitored levels of blood of Immunoglobulins (IgG, IgA and IgM), complement factors (C3 and C4), lymphocyte subpopulations ( $T, B$ and natural killer (NK) cells) in 50 consecutive patients with a diagnosis of severe sepsis or septic shock at three moments during their hospitalization in the ICU. Our measurement of these parameters provide a first assessment of the status of both humoral and cellular arms of the immune response, and their evaluation is easily available in the vast majority of hospitals with critical care medicine units.

\section{Materials and methods \\ Patients \\ Inclusion criteria}

Patients ages 18 years and older with a diagnosis of severe sepsis or septic shock upon admission to our ICU were prospectively and consecutively recruited from January 2010 to January 2011. The first day following ICU admission was considered day 1 in the analysis. 'Sepsis' was defined as suspected infection in the presence of two or more systemic inflammatory response syndrome criteria [9]. 'Severe sepsis' was defined as sepsis plus sepsis-induced organ dysfunction or tissue hypoperfusion [10]. Sepsis-induced hypotension was defined as systolic blood pressure (SBP) $<90 \mathrm{mmHg}$, mean arterial pressure $<70 \mathrm{mmHg}$ or SBP decrease $>$ $40 \mathrm{mmHg}$ or $<2$ SD below normal for age in the absence of other causes of hypotension. 'Septic shock' was defined as hypotension ( $\mathrm{SBP}<90 \mathrm{mmHg}$ ) despite adequate fluid resuscitation $(>1,500 \mathrm{ml})$ or the use of vasoactive agents [10]. Severity of illness was assessed on the basis of two scores: the Acute Physiology and Chronic Health Evaluation II (APACHE II) score for the first 24 hours following diagnosis [11] and the Sequential Organ Failure Assessment (SOFA) score [12].

\section{Exclusion criteria}

Exclusion criteria were the presence of immunodeficiency or concomitant immunosuppressive therapy, pregnancy, do not resuscitate status and cardiac arrest. Approval of the study protocol for both the scientific and ethical aspects was obtained from the Scientific Committee for Clinical Research of our hospital. Informed consent was obtained directly from each patient or his or her legal representative before enrolment.

\section{Microbiological diagnostics}

Standard cultures in biological samples guided by the presumptive source of the septic insult were performed to assess the presence of bacterial and fungal infection [13], along with detection of a urinary antigen test for Legionella pneumophila or Streptococcus pneumoniae. In addition, two consecutive identifications by the LightCycler SeptiFast Test MGRADE (Roche Molecular Diagnostics, Pleasanton, CA, USA) real-time PCR in blood were also considered a positive result. Potentially contaminant microorganisms were not considered.

\section{Immunological laboratory workup}

A serum sample was collected from each patient at day 1 , day 3 and day 10 following admission to the ICU. IgG, IgM, IgA, C3 and C4 levels in serum were measured by using a Dade Behring BN II System nephelometer (Siemens Healthcare Diagnostics, Deerfield, IL, USA). A blood sample was collected in parallel by using tubes containing ethylenediaminetetraacetic acid. Quantification of lymphocytes subpopulations was performed by using BD Trucount tubes (BD Biosciences, San Jose, CA, USA) for enumeration of mature human $\mathrm{T}(\mathrm{CD} 3+)$, B (CD19+), helper/inducer T (CD3+CD4+), suppressor/ cytotoxic T (CD3+CD8+) and NK (CD3-CD16+CD56+) lymphocytes by using a BD FACSCalibur 4-color flow cytometer (342975; BD Biosciences).

\section{Statistical analysis}

Comparison of immune parameters levels based upon mortality were performed using the Mann-Whitney $U$ test. Differences in the levels of immune parameters over the observation period were assessed using the Wilcoxon signed-rank test. We determined the HR and 95\% CI by Cox regression analysis, which was used to assess the impact of independent variables on mortality over time. Multivariate analysis, including age, sex, APACHE II score, severe sepsis or septic shock status and each one of the immunological parameters, was performed. These variables were checked for colinearity prior to inclusion in the regression models using Tolerance and Variance Inflation Factor. We determined the occurrence of death by using Kaplan-Meier curves. Groups were compared by using the log-rank test (Mantel-Haenzel). Logarithmic concentrations of the immune parameters evaluated were employed in the regression analysis to satisfy the linearity assumption. All statistical tests were two-sided, and $P<0.05$ was considered significant. Data analysis was performed using SPSS for Windows version 15.0 software (SPSS, Chicago, IL, USA).

\section{Results \\ Clinical characteristics of the patients}

The majority of the patients of our cohort were elderly and male, with nonsurvivors being older than survivors (Table 1). The most common comorbidities were cardiovascular disease, diabetes and arterial hypertension. Chronic obstructive pulmonary disease was present in many patients who ultimately died during their ICU 
Table 1 Demographics and clinical characteristics of the patients based upon ICU mortality

\begin{tabular}{|c|c|c|c|c|}
\hline Demographic and clinical characteristics & $\begin{array}{l}\text { Survivors } \\
(n=29)\end{array}$ & $\begin{array}{c}\text { Nonsurvivors } \\
(n=21)\end{array}$ & $\begin{array}{l}\text { Total population } \\
(n=50)\end{array}$ & $\begin{array}{c}\text { Survivors vs nonsurvivors } \\
\qquad \text { value }\end{array}$ \\
\hline Age (years) & $66.0(20.0)$ & $72.0(14)$ & $68.5(19.2)$ & 0.048 \\
\hline Males & $18(62 \%)$ & $14(66.6 \%)$ & $32(64 \%)$ & n.s. \\
\hline APACHE II score at ICU admission & $18.0(15.0)$ & $23.0(10.0)$ & $20.5(13.2)$ & n.s. \\
\hline SOFA score at ICU admission & $7.0(6.0)$ & $9.0(2.0)$ & $8.0(4.0)$ & n.s. \\
\hline \multicolumn{5}{|l|}{ Comorbidities } \\
\hline Cardiovascular disease & $8(26.6 \%)$ & $7(35 \%)$ & $15(30 \%)$ & n.s. \\
\hline COPD & $2(6.6 \%)$ & $6(30 \%)$ & $8(16 \%)$ & 0.025 \\
\hline Chronic renal failure or dialysis & $2(6.6 \%)$ & $2(10 \%)$ & $4(8 \%)$ & n.s. \\
\hline Diabetes mellitus types 1 and 2 & $10(33.3 \%)$ & $7(35 \%)$ & $17(34 \%)$ & n.s. \\
\hline Alcohol abuse & $2(6.6 \%)$ & $1(5 \%)$ & $3(6 \%)$ & n.s. \\
\hline Hypertension & $12(41.3 \%)$ & 7 (33.3\%) & $19(38 \%)$ & n.s. \\
\hline Neoplasia & $3(10 \%)$ & $5(25 \%)$ & $8(16 \%)$ & n.s. \\
\hline Obesity & $2(6.6 \%)$ & $1(5 \%)$ & $3(6 \%)$ & n.s. \\
\hline \multicolumn{5}{|l|}{ Diagnostic at ICU admission } \\
\hline Severe sepsis & $11(36.6 \%)$ & $1(5 \%)$ & $12(24 \%)$ & 0.007 \\
\hline Septic shock & $18(62 \%)$ & $20(95.2 \%)$ & $38(76 \%)$ & 0.007 \\
\hline \multicolumn{5}{|l|}{ Presumed source of infection } \\
\hline Lower respiratory tract/pneumonia & $14(46.6 \%)$ & $9(45 \%)$ & $23(46 \%)$ & n.s. \\
\hline Urogenital & $6(20 \%)$ & $3(15 \%)$ & $9(18 \%)$ & n.s. \\
\hline Intra-abdominal & $2(6.6 \%)$ & $3(15 \%)$ & $5(10 \%)$ & n.s. \\
\hline Catheter- or device-related & $1(3.3 \%)$ & $1(5 \%)$ & $2(4 \%)$ & n.s. \\
\hline Skin (soft tissues) & $2(6.6 \%)$ & $1(5 \%)$ & $3(6 \%)$ & n.s. \\
\hline Prosthesis & $2(6.6 \%)$ & $0(0 \%)$ & $2(4 \%)$ & n.s. \\
\hline Central nervous system & $1(3.3 \%)$ & $0(0 \%)$ & $1(2 \%)$ & n.s. \\
\hline Other/unknown & $2(6.8 \%)$ & $4(19 \%)$ & $6(12 \%)$ & n.s. \\
\hline \multicolumn{5}{|l|}{ Documented microbial agent } \\
\hline Gram-positive & $8(26 \%)$ & $6(30 \%)$ & $14(28 \%)$ & n.s. \\
\hline Gram-negative & $10(34.4 \%)$ & $9(42.8 \%)$ & $19(38 \%)$ & n.s. \\
\hline Fungi & $2(6.6 \%)$ & $1(5 \%)$ & $3(6 \%)$ & n.s. \\
\hline
\end{tabular}

Continuous variables are expressed as medians (IQR). All other data are raw numbers (\%). Proportions were compared using the $\mathrm{X}^{2}$ test or Fisher's exact test where appropriate. APACHE II: Acute Physiology and Chronic Health Evaluation II; COPD: chronic obstructive pulmonary disease; SOFA: sequential organ failure assessment score; n.s. $=$ not significant.

hospitalization. Eight patients had an antecedent of solid organ neoplasia with criteria of cure. None of these patients were received chemotherapy or showed evidence of metastasis at the time of admission. Septic shock was the most frequent cause of admission to the ICU, mostly in the group who eventually died. The principal suspected source of infection was the lower respiratory tract. The presence of a microorganism was documented in $72 \%$ of the cases, with a balanced proportion of Gram-positive and Gram-negative bacteria. Two patterns of mortality were observed in our cohort: a group of patients $(n=10)$ died within the 72 hours following admission to the ICU and a group of patients $(n=11)$ who died later than day 3 . All but one of the patients who died presented at admission with status of septic shock. The most frequent cause of death $(n=12)$ was multiorgan dysfunction syndrome. Refractory shock, refractory hypoxemia and cardiovascular events were the causes of the death in the remaining fatal cases. Five nonsurvivors and three survivors received corticosteroids as part of their severe sepsis management. All these patients presented with septic shock, and steroids were administered after the first 24 hours of their ICU stay (hydrocortisone $(50 \mathrm{mg} / 6$ hours or $100 \mathrm{mg} / 8$ hours intravenously).

\section{Comparison of immunological parameters levels based upon outcome}

At day 1 , survivors showed significantly higher levels of IgG and C4 than those who died during hospitalization in the ICU (Table 2). On the contrary, NK cell absolute counts were significantly higher in the group of patients who died. The relative concentrations of NK cells in blood (percentage of total lymphocytes) were also higher in the group of nonsurvivors (median (IQR): survivors = was 9 (12.5) and nonsurvivors $=20(24.5) ; P<0.05)$. 
Table 2 Comparison of immunological parameters based upon ICU mortality

\begin{tabular}{|c|c|c|c|c|c|c|c|c|c|}
\hline \multirow[b]{2}{*}{ Immunological parameters } & \multicolumn{2}{|c|}{$\begin{array}{l}\text { ICU mortality from day } 1 \\
\qquad(N=50)\end{array}$} & \multirow[b]{2}{*}{$P$ value } & \multicolumn{2}{|c|}{$\begin{array}{l}\text { ICU mortality from day } 3 \\
\qquad(N=40)\end{array}$} & \multirow[b]{2}{*}{$P$ value } & \multicolumn{2}{|c|}{$\begin{array}{l}\text { ICU mortality from day } 10 \\
\qquad(N=37)\end{array}$} & \multirow[b]{2}{*}{$\begin{array}{c}P \\
\text { value }\end{array}$} \\
\hline & $\begin{array}{l}\text { Survivors } \\
(n=29)\end{array}$ & $\begin{array}{l}\text { Nonsurvivors } \\
(n=21)\end{array}$ & & $\begin{array}{l}\text { Survivors } \\
(n=29)\end{array}$ & $\begin{array}{l}\text { Nonsurvivors } \\
\quad(n=11)\end{array}$ & & $\begin{array}{l}\text { Survivors } \\
(n=28)\end{array}$ & $\begin{array}{l}\text { Nonsurvivors } \\
\quad(n=9)\end{array}$ & \\
\hline $\operatorname{lgG}(\mathrm{mg} / \mathrm{dl})$ & $844.0(447.5)$ & $616.0(442.5)$ & 0.035 & $932.0(371.0)$ & $685.0(538.0)$ & 0.007 & $1,080.0(602.2)$ & $764.0(1068.0)$ & n.s. \\
\hline $\lg A(m g / d l)$ & $240.0(128.0)$ & $184.0(167.0)$ & n.s. & $280.0(144.0)$ & $240.0(209.0)$ & n.s. & $334.0(164.0)$ & $257.0(580.8)$ & n.s. \\
\hline $\lg M(m g / d l)$ & $53.0(47.0)$ & $60.0(53.0)$ & n.s. & $70.0(85.0)$ & $67.0(61.0)$ & n.s. & $79.5(66.5)$ & $42.0(86.0)$ & n.s. \\
\hline C3 (mg/dl) & $101.5(52.3)$ & $79.0(60.5)$ & n.s. & $108.0(55.0)$ & $110.0(89.0)$ & n.s. & $135.0(49.0)$ & $106.0(81.0)$ & n.s. \\
\hline C4 (mg/dl) & $24.0(19.0)$ & $17.0(16.0)$ & 0.029 & $24.0(16.5)$ & $28.0(22.0)$ & n.s. & $32.0(18.0)$ & $20.0(10.0)$ & n.s. \\
\hline $\mathrm{CD} 3+\mathrm{T}\left(\right.$ cells $\left./ \mathrm{mm}^{3}\right)$ & $417.0(706.5)$ & $419.0(585.0)$ & n.s. & $639.5(636.3)$ & $472.0(415.0)$ & n.s. & $774.0(463.5)$ & $561.0(552.0)$ & n.s. \\
\hline CD4+ T (cells $/ \mathrm{mm}^{3}$ ) & $288.0(474.5)$ & $198.0(400.0)$ & n.s. & $372.5(525.8)$ & $366.0(423.0)$ & n.s. & $519.0(339.0)$ & $347.0(355.0)$ & n.s. \\
\hline CD8+ T (cells $\left./ \mathrm{mm}^{3}\right)$ & $114.0(258.0)$ & $156.0(231.0)$ & n.s. & $249.5(199.0)$ & $120.0(145.0)$ & n.s. & $287.0(296.0)$ & $204.0(314.0)$ & n.s. \\
\hline CD4+ CD8+ T (cells $/ \mathrm{mm}^{3}$ ) & $5.0(12.0)$ & $6.0(13.5)$ & n.s. & $5.0(9.0)$ & $6.5(24.0)$ & n.s. & $12.0(18.3)$ & $6.0(54.0)$ & n.s. \\
\hline LB (cells $\left./ \mathrm{mm}^{3}\right)$ & $103.0(165.5)$ & $184.0(281.0)$ & n.s. & $163.0(125.0)$ & $127.0(168.0)$ & n.s. & $118.0(151.0)$ & $92.0(131.0)$ & n.s. \\
\hline $\mathrm{NK}\left(\right.$ cells $\left./ \mathrm{mm}^{3}\right)$ & $56.8(59.5)$ & $98.0(392.0)$ & 0.050 & $59.5(72.5)$ & $42.0(73.0)$ & n.s. & $86.0(78.0)$ & $92.0(38.0)$ & n.s. \\
\hline
\end{tabular}

Data are expressed as medians (IQR). n.s. = not significant. Normal values in adult healthy individuals are as follows: immunoglobulin G (IgG) $=870$ to 2,180 mg/ $\mathrm{dl}, \lg \mathrm{A}=117$ to $420 \mathrm{mg} / \mathrm{dl} ; \mathrm{lgM}=60$ to $220 \mathrm{mg} / \mathrm{dl} ; \mathrm{CD} 3+\mathrm{T}$ cells $=690$ to 2,540 cells $/ \mathrm{mm}^{3} ;$ CD4+ T cells $=410$ to 1,590 cells $/ \mathrm{mm}^{3} ;$ CD8+ T cells $=190$ to 1,140 cells $/ \mathrm{mm}^{3}$; CD4+ CD8+ T cells = not available; B lymphocytes (LB) $=90$ to 660 cells $/ \mathrm{mm}^{3}$; natural killer (NK) cells $=90$ to 590 cells $/ \mathrm{mm}^{3}$; complement factor 3 (C3) $=50$ to $120 \mathrm{mg} / \mathrm{dl}$; complement factor $4(\mathrm{C} 4)=14$ to $70 \mathrm{mg} / \mathrm{dl}$.

Comparison of immune parameters levels at day 3 evidenced higher levels of IgG in those patients who survived (Table 2). No differences were found at this moment in the course of the disease for the other parameters compared (Table 2). When comparisons were repeated considering only those patients with septic shock $(n=38)$, the same results were obtained (Additional file 1). Survivors exhibited a progressive increase from day 1 to day 10 on most of the immunological parameters evaluated (IgG, IgA, IgM, C3, CD4+, CD8+ $\mathrm{T}$ cells and NK cells) (Additional file 2).

\section{Immune parameters and prediction of mortality}

Multivariate Cox regression analysis showed that NK cell counts at day 1 were independently associated with increased risk of death at 28 days. The median outcome of death at day 28 was 3.34 (95\% CI $=1.29$ to $8.64 ; P=$ $0.013)$. Analysis of the survival curves evidenced that levels of NK cells at day 1 ( $>83$ cells $/ \mathrm{mm}^{3}$ ) were associated with early mortality (Figure 1 ).

When multivariate regression analysis was repeated considering only septic shock patients, NK cell counts at day 1 remained a risk factor for mortality $(\mathrm{HR}=3.20$, 95\% $\mathrm{CI}=1.23$ to $8.35 ; P=0.017)$. IgG levels at day 1 showed a protective association with increased survival at day 28 which was close to statistical significance (HR $=0.10,(95 \% \mathrm{CI}=0.01$ to $1.15 ; P=0.065)$.

\section{Discussion}

Our results provide evidence that differences in the systemic levels of a number of key host immunity elements in patients with severe sepsis influence their final outcome. Compared to those patients who survived, septic patients who died showed lower levels of IgG and C4, along with higher levels of NK cells, in the first 24 hours following admission to the ICU. Comparisons between fatal cases and survivors, as well as the results of our regression analysis, suggest that NK cell counts at day 1 are associated with increased risk of mortality in patients who present to the ICU with severe sepsis. The role of these cells in sepsis is controversial [14]. NK-cell depletion increases survival and decreases systemic levels of cytokines in experimental models of sepsis [7,15-21]. In humans, available data derived from patients in the ICU are scarce, and some of them diverge with the results derived from animal models. Gogos et al. [22] found increased absolute counts of NK cells in sepsis caused by community-acquired pneumonia. Giamarellos-Bourboulis et al. [8] reported improved survival in patients with severe Gram-negative sepsis and high NK counts. NK cells have sophisticated biological functions [23], participating with antigen presentation cells and $\mathrm{T}$ cells in the cellular response against pathogens. NK cells are key actors in innate immunity and as a consequence should play an important role in the very early moments of sepsis. In addition, NK cells could release high amounts of proinflammatory cytokines such as IFN- $\gamma$ or immunosuppressive agents, such as IL-10, thus promoting tissue damage and interfering with the development of the adaptive immune response against the causative microbial agent [23].

When we performed a subanalysis considering only those patients with septic shock, NK cell counts at day 1 were still associated with increased risk of mortality. On the contrary, IgG levels at day 1 showed a protective trend close to statistical significance in the regression analysis. Taccone et al. [5] reported low concentrations of IgG as a common finding in patients with 


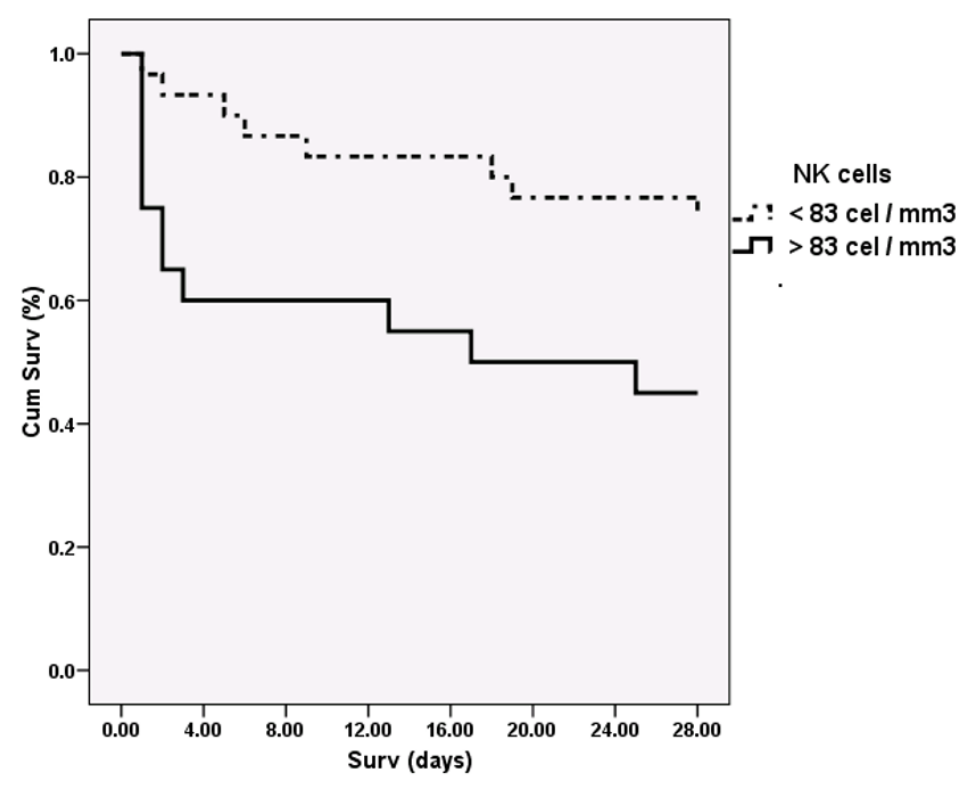

Figure 1 Kaplan-Meier curves. Deciles from percentile 10 to percentile 90 of natural killer (NK) cell counts measured at day 1 were calculated and used to compare survival times in those patients with low or high concentrations of NK cells in their blood. The first decile shows significant differences between groups based upon the log-rank test (Mantel-Haenzel) and was used as the cutoff (percentile $60\left(83 \mathrm{cells} / \mathrm{mm}^{3}\right)$ ). Outcome for this analysis was time until death. Time was censored at day 28. Cum Surv: cumulative survivors; NK: natural killer.

community-acquired septic shock. In their study, patients with hypo-IgG had greater vasopressor requirements, were more likely to develop acute lung injury and/or acute respiratory distress syndrome and had higher mortality. Studies with larger numbers of patients are necessary to confirm the protective trend of IgG in this disease.

The relatively lower levels of $\mathrm{C} 4$ observed in patients who died in our study could be a consequence of consumption of this complement in severe sepsis. In agreement with our results, Nakae et al. [24] found significantly lower levels of C3 and C4 in septic patients who did not survive than in those who did. Analysis of the variations over time in the levels of the immunological parameters evaluated showed that most survivors exhibited a progressive increase from day 1 to day 10 in most of the parameters. This result provides evidence for a compromised host response during the very first moments of severe sepsis (at least from the quantitative point of view) which improves at the latter stages of the disease in these patients. Interestingly, nonsurvivors failed to show significant increments in the levels of the immune parameters measured over time. These findings warrant further work with larger cohorts of patients to evaluate the inclusion of immunological parameters as part of the severity scores in sepsis. A limitation of our study is the definition employed for NK cells (CD3CD16+CD56+ lymphocytes), since it did not include a subset of CD16- NK cells, which account for a minor percentage of total NK cells (5\% to 10\%). Nonetheless, the definition used in this work identified the largest population of these cells.

\section{Conclusions}

Our results demonstrate the prognostic role of NK cells (defined as CD3-CD16+CD56+ lymphocytes) in severe sepsis, proving a direct association of early blood counts of these cells with mortality. Further studies including functional analysis of NK cells are needed to confirm their exact role in the pathogenesis of this disease.

\section{Key messages}

- Being that sepsis originates from a microbial infection, host immunity should play a principal role in determining both outcome and recovery. Identifying quantitative alterations in key humoral and cellular parameters could have a prognostic value in this disease.

- Compared to survivors, septic patients who did not survive showed lower levels of IgG and C4 and higher levels of NK cells in blood in the first 24 hours following admission to the ICU.

- Kaplan Meier curves and Cox regression analysis demonstrate the prognostic role of NK cells (defined as (CD3-CD16+CD56+) lymphocytes) in severe sepsis, evidencing a direct association of early blood counts of these cells with mortality. 


\section{Additional material}

Additional file 1: Comparison of immunological parameters based upon ICU mortality in patients with septic shock. Data are medians [IQR]. n.s = not significant. Normal values in healthy adults are as follows: immunoglobulin $\mathrm{G}(\mathrm{lgG})=870$ to $2,180 \mathrm{mg} / \mathrm{dl} ;$ lgA $=117$ to $420 \mathrm{mg} / \mathrm{dl}$; $\operatorname{lgM}=60$ to $220 \mathrm{mg} / \mathrm{dl} ; \mathrm{CD} 3+\mathrm{T}$ cells $=690$ to $2,540 \mathrm{cells} / \mathrm{mm}^{3} ; \mathrm{CD} 4+\mathrm{T}$ cells $=410$ to 1,590 cells $/ \mathrm{mm}^{3} ; \mathrm{CD} 8+\mathrm{T}$ cells $=190$ to 1,140 cells $/ \mathrm{mm}^{3}$; $\mathrm{CD} 4+C D 8+T$ cells $=$ not available; $\mathrm{B}$ lymphocytes $(\mathrm{LB})=90$ to 660 cells/ $\mathrm{mm}^{3}$; natural killer (NK) cells $=90$ to 590 cells $/ \mathrm{mm}^{3}$; complement factor 3 $(C 3)=50$ to $120 \mathrm{mg} / \mathrm{dl}$; complement factor 4 (C4) $=14$ to $70 \mathrm{mg} / \mathrm{dl}$.

Additional file 2: Comparison of immunological parameter levels over time. Changes in the levels of immune parameters over time in survivors and nonsurvivors were assessed using the Wilcoxon signed-rank test. The results are expressed as medians (IQR) of the increments (day 3 - day 1) and (day 10 - day 1). $\lg G=$ immunoglobulin $\mathrm{G}$; $\lg M=$ immunoglobulin $\mathrm{M}$; IgA = immunoglobulin $\mathrm{A}$; C3: complement factor 3; C4: complement factor 4; NK cells: natural killer cells; $L B=B$ lymphocytes.

\section{Abbreviations}

APACHE II: Acute Physiology and Chronic Health Evaluation II; C3: complement factor 3; C4: complement factor 4; CD: cluster differentiation; COPD: chronic obstructive pulmonary disease; HR: hazard ratio; IFN- $\gamma$ : interferon $\gamma$; Ig: immunoglobulin; IL: interleukin; LB: B lymphocyte: NK: natural killer; PCR: polymerase chain reaction; SBP: systolic blood pressure; SOFA: Sequential Organ Failure Assessment.

\section{Acknowledgements}

The authors thank the ICU nursery team, which kindly collected the samples for the study, and Dr Antonio Orduña for providing logistical support for this work. This study was made possible by a grant from the Spanish Ministry of Science and Innovation and the 'Consejería de Sanidad Junta de Castilla y León' ('Programa para favorecer la incorporación de grupos de investigación en las Instituciones del Sistema Nacional de Salud', EMER07/050, y 'Proyectos de Investigación Sanitaria', PI 10/01362).

\section{Author details}

${ }^{1}$ Critical Care Medicine Service, Hospital Clínico Universitario-SACYL/ SEMICYUC, Avda Ramón y Cajal 3, E-47005, Valladolid, Spain. ${ }^{2}$ Immunology Section and Infection \& Immunity Medical Investigation Unit (IMI), Microbiology and Immunology Service, Hospital Clínico UniversitarioIECSCYL, Avda Ramón y Cajal 3, E-47005 Valladolid, Spain. ${ }^{3}$ Anesthesiology Service. Hospital Clínico Universitario, Avda Ramón y Cajal 3, E-47005 Valladolid, Spain. ${ }^{4}$ Laboratory of Molecular Epidemiology of Infectious Diseases, National Centre of Microbiology, Instituto de Salud Carlos III, Ctra Majadahonda-Pozuelo Km, E-2200 Majadahonda, Madrid, Spain.

\section{Authors' contributions}

$\mathrm{DAO}, \mathrm{FB}, \mathrm{FG}, \mathrm{ROL}$ and JFBM assisted in the design of the study, coordinated patient recruitment, analysed and interpreted the data and assisted in writing the paper. SR, ET, JME, RA and MN assisted in the analysis and interpretation of data and in writing the report. VI, LR, AML, CN, RD and ER performed the laboratory work. All authors read and approved the final manuscript for publication.

\section{Competing interests}

The authors declare that they have no competing interests.

Received: 15 July 2011 Revised: 5 September 2011

Accepted: 21 October 2011 Published: 21 October 2011

\section{References}

1. Angus DC, Linde-Zwirble WT, Lidicker J, Clermont G, Carcillo J, Pinsky MR: Epidemiology of severe sepsis in the United States: analysis of incidence, outcome, and associated costs of care. Crit Care Med 2001, 29:1303-1310.

2. Linde-Zwirble WT, Angus DC: Severe sepsis epidemiology: sampling, selection, and society. Crit Care 2004, 8:222-226.
3. Dombrovskiy VY, Martin AA, Sunderram J, Paz HL: Rapid increase in hospitalization and mortality rates for severe sepsis in the United States: a trend analysis from 1993 to 2003. Crit Care Med 2007, 35:1244-1250.

4. Pierrakos C, Vincent JL: Sepsis biomarkers: a review. Crit Care 2010, 14:R15.

5. Taccone FS, Stordeur P, De Backer D, Creteur J, Vincent JL: $\gamma$-globulin levels in patients with community-acquired septic shock. Shock 2009, 32:379-385.

6. Giamarellos-Bourboulis EJ: What is the pathophysiology of the septic host upon admission? Int J Antimicrob Agents 2010, 36(Suppl 2):S2-S5.

7. Kerr AR, Kirkham LA, Kadioglu A, Andrew PW, Garside P, Thompson H, Mitchell TJ: Identification of a detrimental role for NK cells in pneumococcal pneumonia and sepsis in immunocompromised hosts. Microbes Infect 2005, 7:845-852.

8. Giamarellos-Bourboulis EJ, Tsaganos T, Spyridaki E, Mouktaroudi M, Plachouras D, Vaki I, Karagianni V, Antonopoulou A, Veloni V, Giamarellou H: Early changes of CD4-positive lymphocytes and NK cells in patients with severe Gram-negative sepsis. Crit Care 2006, 10:R166.

9. Bone RC, Balk RA, Cerra FB, Dellinger RP, Fein AM, Knaus WA, Schein RM, Sibbald WJ, ACCP/SCCM Consensus Conference Committee: Definitions for sepsis and organ failure and guidelines for the use of innovative therapies in sepsis. The ACCP/SCCM Consensus Conference Committee. American College of Chest Physicians/Society of Critical Care Medicine. 1992. Chest 2009, 136:e28.

10. Levy MM, Fink MP, Marshall JC, Abraham E, Angus D, Cook D, Cohen J, Opal SM, Vincent UL, Ramsay G: 2001 SCCM/ESICM/ACCP/ATS/SIS International Sepsis Definitions Conference. Crit Care Med 2003, 31:1250-1256.

11. Knaus WA, Draper EA, Wagner DP, Zimmerman JE: APACHE II: a severity of disease classification system. Crit Care Med 1985, 13:818-829.

12. Vincent JL, Moreno R, Takala J, Willatts $\mathrm{S}$, De Mendonça A, Bruining H, Reinhart CK, Suter PM, Thijs LG: The SOFA (Sepsis-related Organ Failure Assessment) score to describe organ dysfunction/failure. On behalf of the Working Group on Sepsis-Related Problems of the European Society of Intensive Care Medicine. Intensive Care Med 1996, 22:707-710.

13. Versalovic J, Carroll KC, Funke G, Jorgensen JH, Landry ML, Warnock DW (Eds): Manual of Clinical Microbiology. 10 edition. Washington, DC: American Society for Microbiology; 2011.

14. Chiche L, Forel JM, Thomas G, Farnarier C, Vely F, Bléry M, Papazian L, Vivier E: The role of natural killer cells in sepsis. J Biomed Biotechnol 2011, 2011:986491.

15. Barkhausen T, Frerker C, Putz C, Pape HC, Krettek C, van Griensven M: Depletion of NK cells in a murine polytrauma model is associated with improved outcome and a modulation of the inflammatory response. Shock 2008, 30:401-410.

16. Emoto M, Miyamoto M, Yoshizawa I, Emoto Y, Schaible UE, Kita E Kaufmann SH: Critical role of NK cells rather than Va $14^{+} \mathrm{NKT}$ cells in lipopolysaccharide-induced lethal shock in mice. J Immunol 2002, 169:1426-1432

17. Heremans H, Dillen C, van Damme J, Billiau A: Essential role for natural killer cells in the lethal lipopolysaccharide-induced Shwartzman-like reaction in mice. Eur J Immunol 1994, 24:1155-1160.

18. Carson WE, Yu H, Dierksheide J, Pfeffer K, Bouchard P, Clark R, Durbin J, Baldwin AS, Peschon J, Johnson PR, Ku G, Baumann H, Caligiuri MA: A fatal cytokine-induced systemic inflammatory response reveals a critical role for NK cells. J Immunol 1999, 162:4943-4951.

19. Goldmann O, Chhatwal GS, Medina E: Contribution of natural killer cells to the pathogenesis of septic shock induced by Streptococcus pyogenes in mice. J Infect Dis 2005, 191:1280-1286.

20. Sherwood ER, Enoh VT, Murphey ED, Lin CY: Mice depleted of CD8+ T and NK cells are resistant to injury caused by cecal ligation and puncture. Lab Invest 2004, 84:1655-1665.

21. Badgwell B, Parihar R, Magro C, Dierksheide J, Russo T, Carson WE: Natural killer cells contribute to the lethality of a murine model of Escherichia coli infection. Surgery 2002, 132:205-212.

22. Gogos C, Kotsaki A, Pelekanou A, Giannikopoulos G, Vaki I, Maravitsa P, Adamis S, Alexiou Z, Andrianopoulos G, Antonopoulou A, Athanassia S, Baziaka F, Charalambous A, Christodoulou S, Dimopoulou I, Floros I, Giannitsioti E, Gkanas P, loakeimidou A, Kanellakopoulou K, Karabela N, Karagianni V, Katsarolis I, Kontopithari G, Kopterides P, Koutelidakis I, Koutoukas P, Kranidioti H, Lignos M, Louis K, et al: Early alterations of the 
innate and adaptive immune statuses in sepsis according to the type of underlying infection. Crit Care 2010, 14:R96.

23. Vivier E, Raulet DH, Moretta A, Caligiuri MA, Zitvogel L, Lanier LL,

Yokoyama WM, Ugolini S: Innate or adaptive immunity? The example of natural killer cells. Science 2011, 331:44-49.

24. Nakae H, Endo S, Inada K, Yoshida M: Chronological changes in the complement system in sepsis. Surg Today 1996, 26:225-229.

doi:10.1186/cc10501

Cite this article as: Andaluz-Ojeda et al:: Early natural killer cell counts in blood predict mortality in severe sepsis. Critical Care 2011 15:R243.

Submit your next manuscript to BioMed Central and take full advantage of:

- Convenient online submission

- Thorough peer review

- No space constraints or color figure charges

- Immediate publication on acceptance

- Inclusion in PubMed, CAS, Scopus and Google Scholar

- Research which is freely available for redistribution

Submit your manuscript at www.biomedcentral.com/submit
C Biomed Central 